УДК 343.614

\title{
SUICIDE IN THE LAW APPLICABLE IN POLAND UNTIL 1970
}

\author{
A. Wrzyszcz \\ Maria Curie-Skłodowska University in Lublin, \\ Pl. M. Curie-Skłodowskiej 5, Lublin, Poland, 20-031, \\ e-mail:awrzyszcz7@wp.pl
}

The article contains the characteristics of suicide regulations in various legal systems that were in force in Poland until 1970. Until the mid-eighteenth century, legal regulations which were in force in the territory of the Polish state, either did not refer to suicide at all, or penalized them quite gently (religious law, German law in cities and in villages located on German law). The Enlightenment reforms unexpectedly sharpened the punishability of suicide (both in Polish legal reform projects and in the codifications of the partitioning powers). Minimizing penalisation, or even its complete liquidation, was brought only by the legal codes of the second half of the nineteenth century and the first half of the twentieth century (Prussian, German, Austrian, Russian, Polish).

Keywords: polish penal law, history of law, polish penal codes.

DOI: http://dx.doi.org/10.30970/vla.2018.67.247

The accounts on the issue of suicide governed by laws applicable in the territories of ancient Poland (this term refers to the history of Polish statehood from its beginnings in the mid-10th century until the era of the partitions of Poland) are very scarce. It seems that at the dawn of the Polish State, pagan Slavic customs could be still in use, according to which widows decided to voluntarily commit suicide after the death of their husbands by ascending the funeral pile. One cannot forget about the legend referring to the patriotic attitude of Princess Wanda of Krakow. She committed suicide by throwing herself into the Vistula River to avoid being married to a German leader [1, p. 77; 14, p. 46].

The stabilization of Polish statehood resulted in various legal systems in force for several hundred years until the second half of the eighteenth century (Polish customary land law, German law applicable in cities, religious law regarding adherents of different religions). The Polish customary land law did not penalise suicide [17, p. 335]. I did not find any references on this subject in contemporary fundamental publications referring to the law in force in cities in historical Poland in relation to people who were successful in killing themselves $[27 ; 28 ; 33 ; 34]$. Neither the Sachsenspiegel nor Constitutio Criminalis Carolina provided for punishment for suicide. These regulations contained no such sanctions as «burning the corpse or running the corpse by a river or, finally, holding a ridiculing funeral ceremony» [28, p. 223]. However, the penalisation of attempted suicide deserves a separate reflection. Marian Mikołajczyk cites such examples. One of the defendants in the trial was a man who had made preparations to kill himself by hanging, but he testified before the court that these preparations had been intended just to scare another person (he wanted to put pressure on his stepson). In some other cases, suicide attempts were committed by prisoners awaiting trial for other crimes. The suicide attempts were recorded in trial files, but these offenders were sentenced for other acts (sacrilege, robbery) [28, p. 223-224; 34, 46-48]. It also seems that for suicides in witch trials, the punishment of corpse burning at the stake was not a sanction for suicide, but the acknowledgement of the witchcraft charges. "Suicides of witches or their deaths during tortures were just explained by inspiration from the devil who was allegedly

(C) Wrzyszcz A., 2018 
accompanying the woman, even during torture and in the courtroom, not allowing her to tell the truth. And when he saw his accomplice wanted to speak, he helped her to leave her life in order to prevent the disclosure of diligently guarded devil's secrets». $[6, \mathrm{p}$. 120]. I did not find penalties for suicide in the Lithuanian law applicable in the territories of the Polish-Lithuanian Commonwealth either [9].

On the other hand, the religious law provided for the practice of sanctions for people who took their own lives. These included a refusal of funeral and burial in the sacred ground [10, p. 140; 17, p. 335].

It should be clearly stressed that the political system realities of ancient Poland (patrimonial monarchy, system of estates of the realm, nobles' Commonwealth) have not led to the introduction in the court law of severe penalties imposed on suicides who effectively took their own lives, which can be observed in other European countries. During the same period (until the second half of the 18th century) in France, in various regions, suicide corpses were hung by the feet, dragged along the streets, male corpses were hanged, female corpses were burned. During the reign of Louis XIV in 1670, this matter was formally regulated in much detail. Posthumous punishment of suicides included dragging the corpse on a rope along the streets, then hanging or throwing it on a garbage heap. Their property was subject to confiscation; in the cases of noblemen their palaces were burnt and trees cut down. Penalisation of suicide was also provided for by the Danish Code of 1683. It prohibited a church funeral and a grave in the cemetery. It introduced confiscation of the suicide's property for the benefit of the king. These sanctions did not apply to cases of suicide due to illness or insanity. Drastic repression was applied to suicide corpses in England (impaling and dragging along main roads, posthumous execution, burial on crossroads, seizure of the abandoned property by the Crown). In Switzerland, corpses of the deceased were quartered and spread to the four corners of the world. The Russian and Spanish regulations were also irrational. [16, p. 21-22; 35, p. 148; 37, p. 362].

In the practice of municipal governments in ancient Poland, there were also cases of reprisals against suicide corpses (for example in Żywiec and its surroundings, suicide corpses were dragged, quartered by executioners, burned at the stake, buried outside cemeteries), but according to the assessment of contemporary historians these were not sanctions included in the legal provisions applicable in cities and towns of the prepartition Poland (see the title hereof). It seems that these penalties were not imposed by courts, but simply executed under customary rules. The Polish legal literature from the sixteenth century discussed also the need to confiscate the property of a suicide, who committed this act for fear of being punished [34, p. 179-180].

We can see an unexpected paradox at the end of the 18th century. The previous (relatively liberal in my opinion) legislation in force in Polish territories became clearly more severe in some areas. It was a completely unusual trend. As a rule, Enlightenment reforms taking place in various countries in the late 18th century and the early 19th century caused de-penalisation of deeds that were hitherto subject to prosecution (e.g. irrational punishment of witchcraft, magic, heresy, apostasy) [40, p. 42; 41, p. 51-52; 42, p. 283-287]. While we can cite other examples regarding suicide. The draft codification entitled «Zbiór praw sądowych» («Set of court laws») developed by Andrzej Zamoyski at a dozen or so years before the fall of the Polish statehood provided for the incorporation of suicide in the catalogue of offences violating the individual's goods and constituting public offences [5, p. 253-254; 24, p. 64].

After the Polish State fell as a result of three consecutive partitions (1st - 1772, 2nd 1793, 3rd - 1795), acts of suicide were assessed in the Polish territories under the regulations of codifications of the partitioning powers. 
As regards suicide, it is indeed possible to cite the views of scholars about modern regulations in force in the Polish territories under Prussian rule. According to them, severe punishments for people who took their own lives were abolished in Prussia as soon as in 1747 and 1751 (cabinet orders of King Frederick II). They were allowed to be buried in cemeteries designed for regular people. In 1798, all sanctions against people attempting suicide were abolished [3, p. 654; 16, p. 22]. The procedure for introducing the laws in force in the Kingdom of Prussia to the lands acquired in three successive partitions of Poland was quite complicated [39, p. 203-205]. My view is that the opinion on the lack of penalties for suicide is too optimistic. Stanisław Salmonowicz states that Frederick II «abolished the application of criminal sanctions for attempted suicide (leaving, however, the requirement of a dishonourable funeral, which was both a compromise in comparison to the practice of the Church and the expression of certain populist views)» [40, p. 199].

The provisions of the General Prussian Land Law of 1794 (Prussian Landrecht) had suicide provisions placed in the last twenty titles governing criminal law. Relevant provisions are found in chapter eleven entitled On bodily injures. Though they provided for that suicides after their death were not to be abused, but they would lose the right to celebrate their memory like other dead people. The suicides of those who committed these acts so as not to be exposed to «shaming punishments» were regulated in a special way. These people were to be buried on the site of execution. The provision on cases of suicide which followed the sentence of death penalty went even further. It provided for the possibility of executing a capital punishment on the corpse of a suicide as a «cautionary» punishment which however had to be carried out «with dignity» [35, p. 148; 43, p. 803-805]. It should be added that the provisions of substantive criminal law were also applicable in the areas of the Duchy of Warsaw and the Kingdom of Poland until 1818 [20, p. 72-73, 137, 142].

The suicide-related provisions of the Prussian penal code of 1851, which formed the basis for the penal code of the North-German Union of 1870, were of key importance for Polish territories under Prussian rule. This code was proclaimed, by the Act of 15.05.1871, the Penal Code of the German Reich [25, p. 262; 46, p. 61-62]. These codes completely ignored suicide as a matter of criminal law.

The second partitioning power was the Habsburg monarchy. In the lands of the Polish state seized by the Habsburg monarchy as a result of the partitions, the provisions of the Constitutio Criminalis Theresiana of 1768 were not introduced as it «profoundly differed from the Polish law». However, the Constitutio Criminalis Theresiana was in force in the so-called Austrian Silesia. It is worthwhile to recall the content of these regulations. Article 93 of this codification provided for the deprivation of the suicide of a religious burial ceremony, property confiscation and infamy of his memory $[3, \mathrm{p} .776$; 20, p. $38 ; 40$, p. 74-75].

The reforms of Emperor Joseph II resulted in significant changes. During the codification work, he supported the «continuation of application of the sanction of a dishonourable funeral to those suicides who died without repentance». He allowed the possibility of confiscation of property in some cases [40, p. 86]. Of course, the Polish territories under Austrian rule were under provisions of the penal code of 1787 (so-called Josephina, Allgemeines Gesetz über Verbrechen und derselben Bestrafung) [20, p. 38; 40, p. 74-75]. Then the punishment of suicide as crimes against religion was abolished. Nonetheless, dichotomous solutions were used. On the one hand, attempted suicide was penalized. A probationary measure (according to today's penal terminology) was applied against a would-be suicide (if sane). He was to be detained for some time to «improve himself». The departure from punishing suicides who accomplished their intention was undoubtedly progressive, as was the withdrawal from prosecution of people «who are not 
sane». However, it is worth noting that the custom, according to which the suicide who had not repented was buried by an executioner, remained. These regulations were in force in the Polish territories seized by Austria in the first partition of 1772 [3, p. 777-780; 40, p. 100-101].

For Polish territories seized by the Habsburg monarchy during the third partition (the so-called Western Galicia) special regulations were enacted. On 1 January 1797, the so-called Western Galician Penal Law of 1796 became effective. This was in fact a draft nation-wide regulation introduced earlier in a limited territory, and then within the entire Habsburg empire. The content of the Western Galician Penal Law was extensively copied in the all-Austrian code of 1803, commonly known as Franciscana (there were very few substantive and stylistic changes as compared to the Act of 1796) [3, p. 780 781; 12, p. 132-134, 147-148].

In Section 139 of the Western Galician Penal Law, attempted suicide was treated as a crime, but the maximum punishment stipulated was quite lenient (from 3 months to 1 year in prison). The provisions about the shameful form of the funeral of suicides continued to apply [3, p. 782; 40, p. 131-132].

On the other hand, the nation-wide Austrian codification of substantive criminal law was, as mentioned above, the code of 1803 , commonly referred to as Franciscana. It brought about mitigation of punishability of suicide. If a man attempted to take his own life and as a result injured or cut himself, but voluntarily gave up his suicidal intention («due to the very remorse»), he was to be severely admonished. However, if it was an attempt that failed only by accident, the perpetrator had to «be taken into custody, and kept under strict supervision until he regains reason and learns about his duties to the Creator, society and himself through moral and physical means, and until he shows remorse for his offence, and until one can expect that his attitude guarantees better conduct in the future» [22; p. 48-49]. In the case of a successful suicide attempt, the deceased's body was to be transported under guard to a place distant from the cemetery and buried there by court officials [22; p. 49]. If, through this act, a suicide who was the perpetrator of another crime avoided punishment, he/she could be stigmatized by a public announcement. This concerned prohibited acts that caused a «great depravation». The announcement was to contain a short description of the crime he/she committed (provided that it was lawfully proven to him/her) [40, p. 141-142, 147, 162; 22; p. 108-109].

When rearranging substantive criminal law in the Habsburg monarchy in the midnineteenth century, a patent was issued on 17 January1850, which repealed the provisions on the offence of suicide [13, p. 447]. This regulation was maintained by the Austrian criminal law of 27 May 1852. Similarly to the Polish lands under Prussian rule, suicide ceased to be an act threatened by sanctions provided for in the generally applicable criminal law [4]. However, it is worth noting that although the very word «suicide» is not mentioned in the wording of the penal act of 1852, this problem has not been ignored by the scholarly opinion. An outstanding Polish criminal law scholar, Edmund Krzymuski, stated that «the Austrian Code does not punish suicide, nor does it define, as a separate offense, aiding to commit it». However, when citing the abundant penal literature in the Habsburg monarchy, he supported the view that aiding to commit suicide should be qualified as a crime against the safety of life. According to him, this was due to the provisions of the Act, which, although they did not punish suicides, did not always allow one's life to be put at risk. This applies, for example, to bathing or iceskating in unauthorized places [21, p. 248-251].

In the Duchy of Warsaw (1807-1815), the above-mentioned Prussian regulations on suicide were in force and (for the south-eastern part of the Duchy in 1809-1815) the regulations of above mentioned Franciscana of 1803 were applicable. 
This state survived for the first three years of the existence of the Kingdom of Poland (1815-1818). A significant change was brought about by the introduction of the penal code of the Kingdom of Poland. It was introduced by the Act of the Sejm of the Kingdom of Poland of 14 April 1818 [38, p. 3-292]. The issue of suicide was governed by Articles 586 and 587. In the first of them, sanctions were imposed on those attempting to commit this offence but were unsuccessful. They were subject to police supervision, which was to protect them, but also to make them observe relevant religious rules. In article 587, a prohibition of solemn funeral ceremonies and commemoration of tombstones was provided for $[32,144 ; 38$, p. 290-291]. Jerzy Śliwowski believes that «The basis for the punishability of suicide is not so much the social harmfulness of the act but rather the idea that a man trespassed a religious prohibition by trying to kill himself» [44, p. 283]. Similar reasoning was offered by outstanding nineteenth-century Polish lawyer Romuald Hube. He states: «... for moral and religious reasons, suicide is a forbidden act» [15, p. 249-251].

A clear step back occurred after the introduction of the Criminal and Correctional Punishments Code in the Kingdom of Poland in 1847. To a significant extent, it referred to the Russian code of 1845 [2, p. 439-440]. Unfortunately, sanctions were restored with regard to suicides who accomplished their intention (actually with regard to their heirs). If someone took his or her life intentionally (with the exception of «insanity, unconsciousness of the mind due to illness»), it was considered that he or she had no right to perform legal action in contemplation of death, and thus his or her testament and other statements were annulled. He was also deprived of Christian funeral [18, p. 683]. As regards a person who consciously attempted suicide (and met the above-mentioned criteria), but for reasons beyond his or her control it was a failed attempt, religious sanctions were provided for (church penance as ordered by organs of the clergy competent for the religion professed by the would-be suicide). The liability of people attempting to kill themselves (whether successfully or unsuccessfully) was excluded if their deeds resulted from noble sacrifices, aimed at maintaining secrecy and other similar cases. It also referred to women fighting for the protection of honour and shame against the threat of rape. However, incitement and aiding to suicide in its were subject to punishment. Special regulations concerned people who by their behaviour could make their subordinates decide to commit suicide (parents, guardians and other persons exercising any other power over others). If they abused this power with severity and thus led to a suicide committed by people subordinated to them, they were subject to criminal liability. The sanctions included: loss of some special rights and privileges, imprisonment at a correction house (from one to two years). Christian offenders were also threatened by ecclesiastical penance imposed by their respective ecclesiastical authorities [18, p. 685].

Issuing rulings on the deprivation of a Christian funeral was a responsibility of police courts, while the responsibility to invalidate testaments and wills was transferred to the civil justice department (civil courts were not bound by findings of the police court and could conduct their own investigative proceedings in the case). Incitement to suicide («and any involvement in it») was treated as complicity in intentional homicide. It was subject to liability in accordance with Article 128 of the Code [18, p. 75; 26, p. 107-112, 215-217, 403-405].

In 1876, a very important reform of the civil and criminal procedure took place in the Kingdom of Poland (the Russian legal acts of 1864 were introduced at that time). At the same time, the Russian Penal Code of 1866 became applicable. In practice, it was only another amendment of the code of 1845 which by no means affected the provisions on suicide (namely Articles 1472-1476) [7, p. 28-30; 12, p. 238-239; 35, p. 149; 45, p. 112-113].

It is also worth referring to the writings of the prominent Polish representative of the studies on criminal law of that era, Stanisław Budziński. He clearly rejects the idea of 
penalisation of suicide, but as a subject of the Russian Emperor, he tries to find the justification for these provisions. He points out that they may discourage people from attempting to kill themselves. He clearly criticizes, though, the provision on annulment of a testament unfairly detrimental for third parties and equal punishability of instigators and participants (people who participated in it). He has also negative opinion about the liability of parents, guardians and other persons who exercise any authority over others. He finds it is difficult to demonstrate a causal link between «harsh treatment» and suicide, and he argues that it would be enough to impose penalties for «harsh treatment» itself. He also refers to the legislation applicable in other countries at that time: England, France, Baden, Brunswick, Saxony, Spain, Brazil, Tuscany, Switzerland, Denmark and others. (e.g. confiscation of the suicide's property in English law and funeral restrictions under that law, similar to Russian regulations) [7, p. 27-30; 35, p. 188-189].

The so-called Tagantsev Code was introduced to the Polish territories in special circumstances. The fragments of our interest, regarding acts of suicide, became an applicable law only during the First World War. The Russian code of 1903 began to be effective on the territory of the Kingdom of Poland occupied by Germany pursuant to the General-Governor Hans von Beseler's ordinance of 8 September 1915 (it was probably issued by mistake - Beseler mistakenly assumed that these provisions had already been fully applicable). In the territories of the Kingdom of Poland occupied by AustroHungary (General Governorate of Lublin), the Tagantsev Code entered into force pursuant to the ordinance of the Provisional Council of State dated 7 August 1917. In the lands further to the east, the orders of the German army's commander-in-chief in the East were binding [20, p. 141-142, 235-236].

The Tagantsev Code code no longer penalised the suicide itself. The regulations contained therein provided for the punishability of aiding and incitement to suicide (Articles 462-463). Article 462 provided for liability of those who provided means to commit suicide if this resulted in the suicide. They were subject to the punishment of one to three years in prison or imprisonment in a fortress for up to three years [31, p. 84-86; 35, p. 189-190]. Wacław Makowski, a renowned Polish scholar of criminal law in the inter-war period, criticized these solutions. He stated that aiding suicide was in «close relation to homicide on demand» which was governed by Article 460. He questioned the idea of building a construct of complicity in suicide, which for the principal perpetrator was essentially unpunished. He concluded that the reason for penalisation of aiding, which consists in providing the «suicide with means to accomplish this intention» was rather to protect the general social order than to protect the life of the suicide himself or herself. According to Wacław Makowski, activities subject to prosecution did not involve rendering any assistance to the suicide, but «only providing the means for taking one's life». The basis for liability was intentional fault in the form of direct or oblique intent. It was made dependent on whether the fully conscious perpetrator provided means that could and were intended to be used to commit suicide by another person or not. The motives that led him to do this (such as pity, profit motives) were irrelevant from the point of view of qualifying his actions as criminal. On the other hand, they had an effect on the type of punishment: not dishonouring (fortress imprisonment), dishonouring (prison). A condition independent of the will of the perpetrator was whether the suicide was successful (attempted suicide did not have negative consequences for the perpetrator). In addition, the act of deprivation of life had to be performed using means provided by the perpetrator (e.g. so it was not the case if the perpetrator provided poison, while the death resulted from hanging) [31, p. 84-86].

Article 463 of the Tagantsev Code provides for the liability of the inciter. This provision, however, caused serious controversy. The word «incitement» was not used, 
perhaps because incitement refers to crime, while suicide was not qualified as such. The term «soliciting suicide» was used instead, but the penalisation covered only this conduct towards people under 21 , or in relation to a person, about whom the perpetrator knew that he or she was unable to understand the essence and meaning of a suicide act or to manage his or her behaviour. It was punishable to provide advice or guidance to such persons, to provide them with a means or to remove an obstacle, if as a result of these activities the suicide was attempted or accomplished. It seems that the latter activities were in the category of aiding. The basis for liability was intentional fault in the form of direct or oblique intent. The sanction provided for in Article 463 was the punishment of imprisonment in heavy prison from four to eight years [31, p. 86-88].

The matter of suicide also appeared in the provisions ofArticle 488 of the Tagantsev Code. The literature usually contains remarks on the so-called «American duel». The text of the provision is as follows: «The person guilty of entering into an agreement with an opponent, making the suicide of one of them conditional upon chance or another event agreed, if suicide has occurred as a result of such an agreement, shall be punished with the penalty of heavy prison for four to eight years. If, as a result of such an agreement, there was only an attempted suicide, not accomplished because of circumstances independent on the will of those who entered into the agreement, the guilty shall be sentenced to imprisonment for a period of one to six years. The same penalties and the same conditions shall apply to the person inciting to such an agreement and cooperating in its conclusion»». As we can see, there is a clear similarity to incitement to suicide. However, significant differences can be identified also. In the event of unsuccessful attempt to commit suicide, both the unsuccessful suicide and the inciter were not held liable. However, the provisions on the "American duel» provided for the penalisation of both participants of such a duel, if an unsuccessful suicide attempt was undertaken. However, if the participant of the «American duel» withdrew voluntarily before undertaking or attempting the suicide, or as a result of being released from the obligation by the other participant, they were not subject to any liability [8, p. 62-63; 31, p. 132-134].

Once Poland regained independence in 1918, three criminal law systems were in force until 1932. As regards suicide, in the territories of the former Prussian partition, the abovementioned German Penal Code of 1871 applied, in the area of the former Austrian partition, the Act of 1852 discussed above applied, while in the former Kingdom of Poland and in the former Russian Partition, the provisions of the Tagantsev Code with changes made by the authorities of the Polish state. The codification efforts carried out in the Second Polish Republic led to the unification of substantive criminal law in the first half of the 1930s. The greatest merits should be credited to the Codification Commission, in particular to its section of substantive criminal law, in which the most prominent scholars and practitioners of substantive criminal law worked (including Juliusz Makarewicz, Wacław Makowski, Aleksander Mogilnicki, Stanisław Emil Rappaport) [2, p. 503, 515].

The modern, fundamental to Polish criminal law in the 20th century, penal code of 1932 (commonly referred to in the literature as Makarewicz and Makowski Code) regulated the liability for suicide with the clear influence of the provisions of the Russian Code of 1903. In contrast to Austrian legislation, no efforts were taken to determine punishability under general provisions on aiding [21, p. 248-251]. According to the Tagantsev Code, penalisation of aiding and inciting to suicide and «American duel» was established. The relevant provisions are Articles 228 and 229 of the Criminal Code of 1932. However, in my opinion, they were definitely more laconic, yet extremely precise.

Article 228 stated: «Whoever by soliciting or aiding, makes a human being take his or her own life shall be punished by imprisonment of up to 5 years» [36, p. 123]. 
Incitement (solicitation) and aiding were treated as independent offences (delictum sui generis). Thus, inciter or aider was not a participant in someone else's crime, but an independent perpetrator of another person's suicide act. The condition of liability was a causal link between the perpetrator's conduct and the act of suicide, of course if the suicide was accomplished or attempted. His responsibility depended on whether solicitation or assistance were factors that strongly influenced the decision on the act of suicide [11, p. 398-399; 30, p. 398-399; 36, p. 123].

Article 229 governed the so-called «American duel». This brief provision reads as follows: "Whoever enters into an agreement which provides for the game of chance about which party is to take his own life, shall be punished by a sentence of imprisonment for up to 5 years». The crime was committed at the time of the conclusion of the agreement which made suicide dependent on chance, and the perpetrators were both parties. It was irrelevant whether the suicide or attempted suicide actually occurred or whether the winner of the «American duel» demanded that the agreement be performed. The latter circumstance could have had an impact on mitigating the penalty [11, p. 729-731; 30, p. 399; 36, p. 123].

The provisions of the Makarewicz and Makowski Code of 1932 were so universal that they were maintained in the People's Republic of Poland after 1944 [23, p. 110]. The regulations referring to the «American duel» were not applied in practice.

Regulations penalising incitement and aiding to suicide were maintained in the penal code of 1969. The wording in Article 151 of this Code was almost identical to that of the Code of 1932, and the upper limit of the penalty was identical. A novelty was the lower limit, i.e. six months. The penal code of 1969 did not penalise the «American duel». The provisions concerning suicide can be found in Article 184. Paragraph 1 of this article regulates punishability of physical or moral abuse of a family member, another person who is under permanent or temporary relationship of dependence on the offender, or a minor or vulnerable person (imprisonment from 6 months to 5 years). Paragraph 2 provides for an increase in gravity of the penalty if the consequence of the act is a suicide attempt by the injured person. The perpetrator was then subject to a sanction of deprivation of liberty from one year to ten years [19, p. 4, 41].

To conclude, it should be noted that the criminal law regulations on suicide, applicable in Poland from the beginning of Polish statehood to 1970, were in my view quite indulgent. I formulated this view in relation to the law of «ancient Poland» until the second half of the 18th century. I support this opinion also for the next decades. Although more repressive regulations appeared in the age of Enlightenment and in the first half of the nineteenth century, in the next few decades we can observe rational approach of legislatures towards the act of suicide (this applies both to the codification carried out by the partitioning powers since 1850 and the legislation of the Second Polish Republic). For comparison, suicide was punishable in various countries, such as in Italy (until 1931), England (until 1961), and attempted suicide in the United States of America until the second half of the 20th century [14, p. 116-117; 16, p. 22].

\section{Список використаних джерел}

1. Bardach J. Historia państwa i prawa Polski. Warszawa, 1973. Vol. 1.

2. Bardach J., Leśnodorski B., Pietrzak M. Historia ustroju i prawa polskiego. Warszawa, 2005.

3. Bardach J., Senkowska-Gluck M. Historia państwa i prawa Polski. Warszawa, 1981. Vol. 2.

4. Bodyński M. Ustawa karna z dnia 27. maja 1852 r. z uwzględnieniem wszystkich zmieniających ją ustaw austriackich i polskich oraz z najważniejszymi ustawami dodatkowymi, wydał J. W. Willaume. Lwów, 1924.

5. Borkowska-Bagieńska E. «Zbiór praw sądowych» Andrzeja Zamoyskiego. Poznań, 1986. 
6. Borucki M. Temida staropolska. Warszawa, 1979.

7. Budziński $S$. O przestępstwach w szczególności. Wykład porównawczy z uwzględnieniem praw obowiązujących w Królestwie Polskim i Galicyi austriackiej. Warszawa, 1883.

8. Choynowski Sz. Zarys najważniejszych przestępstw pospolitych zawartych w k.k. oraz w ustawach i rozporządzeniach karnych dodatkowych zestawiony do użytku wojskowych organów spokoju, porządku i bezpieczeństwa publicznego. Grudziądz, 1931.

9. Czacki T. O litewskich i polskich prawach, Vol. 1-2. Warszawa, 1800-1801.

10. Ferenc M. Czasy nowożytne // Obyczaje w Polsce. Od średniowiecza do czasów współczesnych. Praca zbiorowa pod red. A. Chwalby. Warszawa, 2006.

11. Glaser S., Mogilnicki A. Kodeks karny. Komentarz. Prawo o wykroczeniach. Przepisy wprowadzające. Tezy z orzeczeń Sądu Najwyższego. Wyciągi z motywów ustawodawczych. Kraków, 1934.

12. Grodziski S., Salmonowicz S. Ustawa karna zachodniogalicyjska z roku 1796. Zarys dziejów i charakterystyka // Czasopismo Prawno-Historyczne. 1965. Vol. 17. Iss. 2.

13. Grzybowski K. Historia państwa i prawa Polski. Warszawa, 1982. Vol. IV.

14. Hotyst B. Samobójstwo - przypadek, czy konieczność. Warszawa, 1983.

15. Hube R. Ogólne zasady nauki prawa karnego. Warszawa, 1830.

16. Jarosz M. Samobójstwa. Warszawa, 1997.

17. Kaczmarczyk Z., Leśnodorski B. Historia państwa i prawa Polski. Warszawa, 1965. Vol. 2.

18. Kodeks kar głównych i poprawczych, Warszawa, 1847.

19. Kodeks karny, Kodeks postępowania karnego, Kodeks karny wykonawczy, stan prawny na dzień 30 czerwca 1989 r. Warszawa, 1989.

20. Korobowicz A., Witkowski W. Historia ustroju i prawa polskiego (1772-1918). Warszawa, 2012.

21. Krzymuski E. Wykład prawa karnego ze stanowiska nauki i prawa austriackiego. Kraków, 1911.

22. Księga ustaw na zbrodnie i ciężkie policyjne przestępstwa. Wiedeń, 1817.

23. Lityński A. Historia prawa Polski Ludowej. Warszawa, 2010.

24. Maciejewski T. Historia prawa karnego w dawnej Polsce (do 1795 r.) // System prawa karnego, Źródła prawa karnego, ed. T. Bojarski. Warszawa, 2011. Vol. 1.

25. Maciejewski T. Historia ustroju i prawa sądowego Polski. Warszawa 2011.

26. Maciejowski $F$. Wykład prawa karnego w ogólności z zastosowaniem kodeksu kar głównych i poprawczych z dniem 20 grudnia / 1 stycznia 1848 r. w Królestwie Polskim obowiązującego tudzież ustawy przechodniej i instrukcji dla sądów. Warszawa, 1848.

27. Maisel $W$. Ortyle sądów wyższych miast wielkopolskich z XV i XVI wieku. Wrocław, 1959.

28. Maisel $W$. Poznańskie prawo karne do końca XVI wieku. Poznań, 1963.

29. Maisel $W$. Sądownictwo miasta Poznania do końca XVI wieku. Poznań, 1961.

30. Makarewicz J. Kodeks karny z komentarzem. Lwów, 1935.

31. Makowski W. Kodeks karny obowiązujący tymczasowo w Rzeczypospolitej Polskiej na ziemiach b. zaboru rosyjskiego. Warszawa, 1921.

32. Migdat J. Prawo Kodeksu Karzącego dla Królestwa Polskiego z 1818 roku. Gdańsk, 2006.

33. Mikołajczyk M. Proces kryminalny w miastach Małopolski XVI-XVIII wieku. Katowice, 2013.

34. Mikołajczyk M. Przestępstwo i kara w prawie miast Polski południowej XVI-XVIII wieku. Katowice, 1998.

35. Mogilnicki A. Kary dodatkowe. Kary cielesne, kary hańbiące, pozbawienie czci i praw. Warszawa, 1907.

36. Nisenson J., Siewierski M. Kodeks karny i prawo o wykroczeniach. Rozporządzenia Prezydenta Rzeczypospolitej z dnia 11 lipca 1932 r. (Dz. U. R. P. Nr. 60 poz. 571 i 572) z komentarzem opartym na uzasadnieniu Komisji Kodyfikacyjnej i orzecznictwie Sądu Najwyższego, zestawieniem odpowiednich przepisów dotychczasowych, objaśnieniami i skorowidzem wraz $\mathrm{z}$ przepisami wprowadzającymi i utrzymanymi $\mathrm{w}$ mocy przepisami uchylonych kodeksów karnych. Warszawa, no data of edition. 
37. Ptaza S. Historia prawa w Polsce na tle porównawczym, part. I: centuries X-XVIII w. Kraków, 1997.

38. Prawo kodeksu karzącego dla Królestwa Polskiego z dnia 14 kwietnia 1818 r., Dziennik Praw Królestwa Polskiego, t. 5.

39. Radwański Z., Wasicki A. Wprowadzenie Pruskiego Prawa Krajowego na ziemiach polskich // Czasopismo Prawno-Historyczne. 1954. Vol. 6. Iss. 1.

40. Salmonowicz S. Prawo karne oświeconego absolutyzmu. Z dziejów kodyfikacji karnych przełomu XVIII/XIX w. Toruń, 1966.

41. Salmonowicz $S . Z$ wieku oświecenia. Studia z dziejów prawa i polityki XVIII wieku. Toruń, 2001.

42. Sójka-Zielińska K. Historia prawa. Warszawa, 1981.

43. Stawiarski I. Powszechne prawo kryminalne dla państw pruskich, część druga. Warszawa, 1813.

44. Śliwowski J. Kodeks karzący Królestwa Polskiego (1818). Historia jego powstania i próba krytycznej analizy. Warszawa, 1958.

45. Witkowski $W$. Prawo karne na ziemiach polskich w dobie zaborów i w pierwszych latach II RP (17951932) // System prawa karnego. Źródła prawa karnego. ed. T. Bojarski. Warszawa 2011. Vol. 1.

46. Wrzyszcz A. Przestępstwo bigamii w kodeksach karnych obowiązujących na ziemiach polskich w dobie zaborów // Bigamia. ed. M. Mozgawy. Warszawa, 2011.

\section{References}

1. Bardach, J. (1973). Historia państwa i prawa Polski. Do połowy XV wieku, Vol. 1. Warszawa.

2. Bardach, J., Leśnodorski, B., Pietrzak, M (2005). Historia ustroju i prawa polskiego. Warszawa.

3. Bardach, J., Senkowska-Gluck, M. (1981). Historia państwa i prawa Polski. Od rozbiorów do uwłaszczenia, Vol. 3. Warszawa.

4. Bodyński, M. (1924). Ustawa karna z dnia 27. maja 1852 r. z uwzględnieniem wszystkich zmieniajacych jq ustaw austriackich $i$ polskich oraz $z$ najważiejszymi ustawami dodatkowymi. Lwów.

5. Borkowska-Bagieńska, E.(1986). «Zbiór praw sqdowych» Andrzeja Zamoyskiego. Poznań.

6. Borucki, M. (1979). Temida staropolska. Warszawa.

7. Budziński, S. (1883). O przestepstwach w szczególności. Wykład porównawczy z uwzględnieniem praw obowiqzujacych w Królestwie Polskim i Galicyi austriackiej. Warszawa.

8. Choynowski, Sz. (1931). Zarys najważniejszych przestępstw pospolitych zawartych w k.k. 03 oraz w ustawach i rozporzqdzeniach karnych dodatkowych zestawiony do użytku wojskowych organów spokoju, porzqdku i bezpieczeństwa publicznego. Grudziądz.

9. Czacki, T. (t. I 1800, t. II 1801). O litewskich i polskich prawach. Warszawa.

10. Ferenc, M. (2006), Czasy nowożytne [w:] Obyczaje w Polsce. Od średniowiecza do czasów wspótczesnych. Praca zbiorowa pod red. A. Chwalby. Warszawa.

11. Glaser, S., Mogilnicki, A. (1934). Kodeks karny. Komentarz. Prawo o wykroczeniach. Przepisy wprowadzajace. Tezy z orzeczeń Sąu Najwyższego. Wyciagi z motywów ustawodawczych. Kraków.

12. Grodziski, S. (1965), Salmonowicz S. Ustawa karna zachodniogalicyjska z roku 1796. Zarys dziejów i charakterystyka. Czasopismo Prawno-Historyczne, 17, Iss. 2.

13. Grzybowski, K. (1982). Historia państwa i prawa Polski. Od uwłaszczenia do odrodzenia państwa, Vol. 4. Warszawa.

14. Hołyst, B. (1983). Samobójstwo-przypadek, czy konieczność. Warszawa.

15. Hube, R. (1830). Ogólne zasady nauki prawa karnego. Warszawa.

16. Jarosz, M. (1997). Samobójstwa. Warszawa.

17. Kaczmarczyk, Z., Leśnodorski, B. (1965). Historia państwa i prawa Polski. Od połowy XV wieku do r. 1795, Vol. 2. Warszawa.

18. Kodeks kar głównych i poprawczych (1847). Warszawa. 
19. Kodeks karny, Kodeks postępowania karnego, Kodeks karny wykonawczy, stan prawny na dzień 30 czerwca 1989 r. (1989). Warszawa.

20. Korobowicz, A., Witkowski, W. (2012). Historia ustroju i prawa polskiego (1772-1918). Warszawa.

21. Krzymuski, E. (1911). Wykład prawa karnego ze stanowiska nauki i prawa austriackiego. Kraków.

22. Księga ustaw na zbrodnie i ciężkie policyjne przestępstwa (1817).Wiedeń.

23. Lityński, A. (2010). Historia prawa Polski Ludowej. Warszawa.

24. Maciejewski, T. (2011). Historia prawa karnego w dawnej Polsce (do 1795 r.) [in:] System prawa karnego, Vol. 1, Źródta prawa karnego, ed. T. Bojarskiego. Warszawa.

25. Maciejewski, T. (2011). Historia ustroju i prawa sqdowego Polski. Warszawa.

26. Maciejowski, F. (1848). Wyktad prawa karnego w ogólności z zastosowaniem kodeksu kar głównych i poprawczych $z$ dniem 20 grudnia/1 stycznia 1848 r. w Królestwie Polskim obowiqzujacego tudzież ustawy przechodniej i instrukcji dla sąów. Warszawa.

27. Maisel, W.(1959). Ortyle sq̨ów wyższych miast wielkopolskich z XV i XVI wieku. Wrocław.

28. Maisel, W.(1963). Poznańskie prawo karne do końca XVI wieku. Poznań.

29. Maisel, W.(1961). Sqdownictwo miasta Poznania do końca XVI wieku. Poznań.

30. Makarewicz, J.(1935). Kodeks karny z komentarzem. Lwów.

31. Makowski, W. (1921). Kodeks karny obowiqzujacy tymczasowo w Rzeczypospolitej Polskiej na ziemiach b. zaboru rosyjskiego. Warszawa.

32. Migdał, J. (2006). Prawo Kodeksu Karzqcego dla Królestwa Polskiego z 1818 roku. Gdańsk.

33. Mikołajczyk, M. (2013). Proces kryminalny w miastach Małopolski XVI-XVIII wieku. Katowice.

34. Mikołajczyk, M. (1998). Przestępstwo i kara w prawie miast Polski poludniowej XVI-XVIII wieku. Katowice.

35. Mogilnicki, A. (1907). Kary dodatkowe. Kary cielesne, kary hańbiqce, pozbawienie czci i praw. Warszawa.

36. Nisenson, J., Siewierski, M. (no data of edition). Kodeks karny i prawo o wykroczeniach. Rozporzadzenia Prezydenta Rzeczypospolitej z dnia 11 lipca 1932 r. (Dz. U. R. P. Nr. 60 poz. 571 i 572) z komentarzem opartym na uzasadnieniu Komisji Kodyfikacyjnej i orzecznictwie Sqdu Najwyższego, zestawieniem odpowiednich przepisów dotychczasowych, objaśnieniami $i$ skorowidzem wraz $z$ przepisami wprowadzajacymi $i$ utrzymanymi $w$ mocy przepisami uchylonych kodeksów karnych. Warszawa.

37. Płaza, S. (1997). Historia prawa w Polsce na tle porównawczym, part. I: X-XVIII w. Kraków.

38. Prawo kodeksu karzącego dla Królestwa Polskiego z dnia 14 kwietnia 1818 r., Dziennik Praw Królestwa Polskiego, Vol. 5.

39. Radwański, Z., Wąsicki, A. (1954). Wprowadzenie Pruskiego Prawa Krajowego na ziemiach polskich. Czasopismo Prawno-Historyczne, Vol. 6, Iss. 1.

40. Salmonowicz, S. (1966). Prawo karne oświeconego absolutyzmu. Z dziejów kodyfikacji karnych przetomu XVIII/XIX w. Torun.

41. Salmonowicz, S. (2001). Z wieku oświecenia. Studia z dziejów prawa i polityki XVIII wieku. Torun.

42. Sójka-Zielińska, K. (1981). Historia prawa. Warszawa.

43. Stawiarski, I. (1813). Powszechne prawo kryminalne dla państw pruskich, część druga. Warszawa.

44. Śliwowski, J.(1958). Kodeks karzqcy Królestwa Polskiego z 1818 roku. Historia jego powstania i próba krytycznej analizy. Warszawa.

45. Witkowski, W. (2011). Prawo karne na ziemiach polskich w dobie zaborów i w pierwszych latach II RP (1795-1932) [in:] System prawa karnego, Vol. 1. Źródła prawa karnego, pod ed. T. Bojarski. Warszawa.

46. Wrzyszcz, A. (2011). Przestępstwo bigamii w kodeksach karnych obowiązujących na ziemiach polskich w dobie zaborów [in:] Bigamia, ed. M. Mozgawa. Warszawa. 


\title{
САМОГУБТВО ЗА ЗАКОНОДАВСТВОМ ПОЛЬЩ,
} ЯКЕ ДІЯЛО ДО 1970 РОКУ

\author{
А. Вэсищч \\ Університет Марії Кюрі-Склодовської, \\ пл. М. Кюрі-Склодовської, 5, Люблін, Республіка Польща, 20-031, \\ e-mail:awrzyszcz7@wp.pl
}

Охарактеризовано законодавче регулювання самогубства у різних правових системах, які діяли в Польщі до 1970 р.

Дані про правове регулювання питання самогубства на території Стародавньої Польщі (цей термін належить до історії польської державності від ії̈ початку в середині X cт. до епохи поділу Польщі) дуже незначні. Процес стабілізації польської державності призвів до існування різних правових систем на території сучасної Польщі протягом кількох сотень років аж до другої половини XVIII ст. (польське звичаєве право, німецьке право в містах, релігійне право). Правові норми на той час або взагалі не містили вказівки на самогубство, або карали його досить м'яко.

Несподівані зміни ми можемо спостерігати наприкінці XVIII ст. Попереднє (досить ліберальне, на думку автора) законодавство, яке діяло на польських територіях, стало значно суворішим в окремих питаннях. Після падіння Польської держави в результаті трьох послідовних поділів (перший - 1772, другий - 1793, третій - 1795), акти самогубств оцінювали на польських територіях відповідно до положень кодифікацій держав, під владою яких перебували відповідні землі. Внаслідок проведених реформ посилилася караність самогубств.

Незважаючи на те, що в епоху Просвітництва та в першій половині XIX ст. з'явилися більш репресивні положення, в наступні десятиліття ми можемо спостерігати раціональний підхід законодавця до акту самогубства. Мінімізація караності або навіть їі повне скасування було здійснено кодексами другої половини XIX та першої половини XX ст. (прусським, німецьким, австрійським, російським, польським).

Після відновлення незалежності Польщі у 1918 р., на її території діяли три системи кримінального права до 1932 р. Кодиффікаційні роботи, проведені в Другій Польській Республіці, завдячуючи Комісії з кодифрікації, у складі якої працювали найвідоміші науковці та практики кримінального права, призвели до уніфікації матеріального кримінального права в першій половині 1930-х років. Новий Кримінальний кодекс 1932 р. встановлював відповідальність за самогубство з помітним впливом положень російського Кодексу 1903 p. Зокрема, у статтях 228 та 229 було встановлено кримінальну відповідальність за пособництво і підбурювання до самогубства. Ці положення були настільки універсальними, що вони збереглися в Народній Республіці Польща після 1944 р., у тому числі, були майже дослівно перенесені до Кримінального кодексу 1969 р.

На закінчення варто зауважити, що кримінально-правові норми про самогубство, застосовувані в Польщі з початку польської державності до 1970 р., на погляд автора, були досить поблажливими.

Ключові слова: польське кримінальне право, історія права, польські кримінальні кодекси.

Стаття: надійшла до редакції 16.09.2018

прийнята до друку 01.11.2018 